\title{
Creature Symbols to Foreshadow Harry's Confrontation with his Past in J.K. Rowling's Harry Potter and the Prisoner of Askaban
}

\author{
Fabian Firman Elmar \& Maria Ananta \\ f.firman.e@gmail.com \& m_ananta@usd.ac.id \\ Department of English Letters, Universitas Sanata Dharma
}

\begin{abstract}
Symbol is a major element in literary works. It always has a meaning which is different than the literal meaning of the symbol itself, and thus, it is prevalent in literary works which often contain hidden meanings. Foreshadowing on the other hand, is the act of vaguely hinting the readers to the future event in the story or even the outcome of said story. This study discusses the creature symbols presented in J.K. Rowling's Harry Potter and the Prisoner of Azkaban as foreshadowing element that hints towards the confrontation between Harry and his past in the conflict of the novel. There are three creature symbols found in the novel: The black dog, the rat Scabbers, and the dementors of Azkaban. The black dog reflects Sirius' loyalty to his friends and its black fur symbolizes the sorrow and mourning he felt for their death, but its resemblance with the Grim stands for his vengeful obsession to Peter Pettigrew whom had betrayed him and the Potters. The rat Scabbers on the other hand, symbolizes betrayal, cowardice, and cunning trickery, traits that can be found in Peter Pettigrew. The dementors meanwhile, symbolizes hopeless misery and despair known as depression. These guardians of Azkaban foreshadowed that the conflict would be a confrontation between Harry and his past while the black dog and rat revealed the truth behind said past regarding who betrayed the Potters twelve years ago and the innocent man whom said crime was blamed upon.
\end{abstract}

Key words: symbols, foreshadow, J.K. Rowling

\section{Introduction}

In Harry Potter and the Prisoner of Azkaban, J.K. Rowling uses symbols in form of creatures presented in the story. For example, a large black dog which was the animagus form of Sirius Black. A dog is a symbol of loyalty, but the black dog was presented in the story as an omen of death. Peter Pettigrew on the other hand have the animagus form of a rat, a symbol of disease and cowardice.

These creature symbols are used by Rowling to clue in the readers towards the main conflict of the story in which Harry
Potter is confronted by the unknown part of his past, one that is related to the night when his parents, James and Lily Potter, were murdered, and him becoming the Boy-WhoLived, the hero of British magical world. The creatures in the novel, both magical or nonmagical, are an important aspects in Harry Potter universe, especially regarding the third book Prisoner of Azkaban where creatures are prevalent throughout the story, and thus, the writer is going to discuss in this undergraduate thesis how the creature symbols in the novel foreshadow Harry Potter's confrontation with his past as revealed by the plot of the novel. 


\section{Symbols}

Abrams defined a symbol broadly as "anything that signifies something" (1999: 311 ), but he further elaborated the terms in relation to discussing literature as follows:

In discussing literature, however, the term "symbol" is applied only to a word or phrase that signifies an object or event which in its turn signifies something, or has a range of reference, beyond itself (1999: 311).

A symbol then refers to a specific object which signifies a certain meaning, or meanings, which are different than the literal concept of the object. As an example, the event of war as a symbol is not to be taken literally as merely a conflict, but a symbol of chaos, failure of leaders to keep order and peace for their people.

Abrams classified symbols into conventional or public symbols and personal symbols. Conventional symbols refer to "symbolic objects of which the further significance is determinate within a particular culture" (Abrams, 1999: 311). These symbols are conventional because they were not invented by one person, but their meanings were established into place within the culture of a society. Examples of such symbols are sword which in medieval culture of Europe and in the samurai culture of Japan is a symbol for honour and justice, and cross which is the symbol of salvation and victory against evil in the Christian culture. Personal symbols on the other hand, refer to "symbols that are made by exploiting widely shared associations between an object or event or action and a particular concept" (Abrams, 1999: 311). Whereas conventional symbols are the result of culture, personal symbol is an invention of a person, an author, and thus, their meaning is defined in accordance to the author's will and may differs to the symbolic meaning established in a certain culture. For example, a sword, as opposed of being a symbol of honour and justice as established in warrior culture of medieval Europe and Japan, symbolizes war, chaos, and bloodshed instead.
According to Arp and Johnson:

1. A story must furnish a clue that a detail is to be taken symbolically. The symbol always signals their existence through emphasis, repetition, or position (2006: 280).

2. The meaning of literary symbol must be established and supported by the context of the story. A symbol has its meaning in the story, not outside of it (2006: 280).

3 . To be called a symbol, an item must suggest a meaning different in kind from its literal meaning, or in other words, a symbol is something more than a representative of a class or type (2006: 280).

4. A symbol may have more than one meaning. It may suggest a cluster of meaning that is controlled by the context of the story (2006: 281).

Thus, in order to identify a symbol within a literary work, it is necessary for the reader to observe the detail of the work, especially repeated, emphasized, and strategically positioned detail that may pertain clues that an object may be a symbol of importance in the story. The context of the story itself must also support the idea that an object is a symbol, as the use of an object as a symbol must be established within the story and the symbol cannot be referred to as one without it. Lastly, a symbolic meaning of an object is not connected to the object in a literal sense, but it represents something more beyond the object itself, such as an idea or an emotion that are often linked connotatively to the object, and that an object may have a cluster of meaning, each of which is supported by the relevant context of the story.

\section{Foreshadows}

Foreshadowing as a literary term is a "hint or suggestion of what is to come" (Barnet, 2008: 103), allowing readers to glimpse at the future events of the story. This means that foreshadowing is a vague clue that can be found in the story that indicates the readers of upcoming event, character development, or plot progression that will happen later in a story. 
Cuddon states that foreshadowing is "an arrangement of events and information in such way that later events are prepared for or shadowed forth beforehand and thus, gives structural and thematic unity" (2013: 285). Thus, there is a unity in the structure and theme of the novel in a way that the later events happened in the story, such as how the conflict is going to be resolved or how will the character faced his enemy, is already clued in to the readers through connection to earlier scenes and previously given information in the early part of the novel.

\section{Creature Symbols in Harry Potter and the Prisoner of Askaban}

Creatures are intricately tied into the novels of Harry Potter series. Whether it is a common animal, mythical beasts of legend, or the magical creatures of Rowling's own creation, Rowling made the creatures she presented in Harry Potter series as an inseparable part of its universe and often served a role to further the story's plot.

There are creatures Rowling presented which served in particular importance as symbols: The black dog, Scabbers the rat, Buckbeak the hippogriff, the white stag that appeared as Harry's patronus, Hermione's pet cat Crookshanks, and the dementors of Azkaban prison. In this study the black dog, Ron's pet rat Scabbers, and the dementors of Azkaban prison are examined

\section{The Black Dog}

The black dog made a recurring appearance throughout the novel's storyline, shadowing Harry twice just before accidents that nearly killed him and later was revealed to be the animagus form of Sirius Black, a fugitive on the run. The fact that the black dog appeared repeatedly throughout the plot as it shadowed Harry, twice just before the accidents that nearly killed him and once more just before his confrontation with Sirius Black, as well as the revelation of it as Sirius' animagus form confirmed that the black dog is a symbol of importance.
Originally, the black dog was thought to be a Grim, a dog-like creature which Professor Trelawney described in the novel as followed, "the giant, spectral dog that haunts churchyards, an omen-the worst omen—of death" (1999: 118).

If the black dog truly is a Grim, then it is meant to be a symbol of death. However, as Arp and Johnson stated, "the meaning symbol must be established and supported by the context of the story" (2006: 180). Thus, there must be evidence within the novel that support whether the black dog is a Grim that symbolizes death or not.

Ron Weasley's words are found in the novel regarding the subject, "Grim scare the living out of most wizard" (1999: 122) and many students in the Divination class during their first lesson gasped in horror when professor Trelawney announced that Harry had Grim in his tea cup as they understand the significance of Grim.

"My dear," Professor Trelawney's huge eyes opened dramatically, "you have the Grim."

"The what?" said Harry. He could tell that he wasn't the only one who didn't understand; Dean Thomas shrugged at him and Lavender Brown looked puzzled, but nearly everybody else clapped their hands to their mouths in horror. (1999: 118)

It can be concluded that Grim as a symbol of death is a common superstition in the magical world. Thus, it fits Abrams' theory of conventional symbol that it is a "symbolic object which significance is determined within a particular culture" (Abrams, 1999: 311). In this case, the significance of Grim is established within the culture of witches and wizards in the magical world.

The two accidents that occurred immediately following the black dog's appearance, both nearly takes Harry's life, seems to support the possibility that the black dog is indeed a Grim. The first occurred during the night when Harry left Magnolia 
Crescent and the second is on the first quidditch match of the season against Hufflepuff.

While there were no clear implication that the black dog appeared to be spectral in its first appearance as how Trelawney described the Grim, Harry had estimated its size to be very large when he lighted the surrounding area.

What Harry saw at the time was a silhouette which he later affirmed to be something similar to a dog, "There was a big black thing," said Harry, pointing uncertainly into the gap. "Like a dog ... but massive ..." (1999: 37).

Coincided with its first appearance, Harry was almost crushed by the Knight Bus that answered his unintended summon when he accidentally waved his wand arm as he fell. Harry had brushed with death at the time. He thought little of the incident until he saw the cover of a book about death omens in Flourish and Blotts which had the picture of a black dog similar to the one he saw at the night, but even then he tried to assure himself that it was just a stray dog (1999: 59-60).

The black dog made a second appearance during the first game of quidditch in the season between Gryffindor and Hufflepuff. Again, the Grim appeared this time as a silhouette, though Harry could clearly made out its form.

He turned, intending to head back toward the middle of the field, but at that moment, another flash of lightning illuminated the stands, and Harry saw something that distracted him completely-the silhouette of an enormous shaggy black dog, clearly imprinted against the sky, motionless in the topmost, empty row of seats (1999: 197).

As with the dog's first appearance, the incident occurred following its presence endangered Harry's life.
Numbing, swirling white mist was filling Harry's brain. ... What was he doing? Why was he flying? He needed to help her. ... She was going to die. ... She was going to be murdered. ... He was falling, falling through the icy mist.

"Not Harry! Please ... have mercy ... have mercy. ..." A shrill voice was laughing, the woman was screaming, and Harry knew no more (1999: 199).

As it turns out, despite the two incidents occurred previously pointed to the conclusion that the black dog is a Grim as Harry had feared, Rowling gives a clue that the black dog may not be a Grim in its third appearance.

Crookshanks seemed to have come to a halt. Harry was sure he could see something else moving in the shadow of the trees too. And just then, it emergeda gigantic, shaggy black dog, moving stealthily across the lawn, Crookshanks trotting at its side. Harry stared. What did this mean? If Crookshanks could see the dog as well, how could it be an omen of Harry's death? (1999: 338)

The black dog appeared for the fourth time when it kidnapped Ron into a hidden passage beneath the Whomping Willow.

Ron was on his feet. As the dog sprang back toward them he pushed Harry aside; the dog's jaws fastened instead around Ron's outstretched arm. Harry lunged forward, he seized a handful of the brute's hair, but it was dragging Ron away as easily as though he were a rag doll (1999: 373).

That the black dog could bite Ron and dragged him away is clearly an evidence that it is solid in appearance instead of spectral and thus, is not a Grim. Accordingly, as the evidence disproved the previous hypothesis, there must be something else signified by the black dog.

Towards the climax of the plot, the black dog is revealed to be the animagus form of Sirius Black. As it turns however, Sirius Black 
was never a traitor. He is a loyal friends to Harry's parents and sworn that he "never betrayed James and Lily and would have died before he betrayed them" (1999: 415). He also stated that his reason to break out from Azkaban was to protect Harry as he was the only one who knew that the traitor Pettigrew, servant to Lord Voldemort was still alive (1999: 415). This loyalty is actually reflected in the black dog that is his animagus form. Dog is often depicted as loyal animal and here, the form of black dog Sirius assumed signified the loyalty he held towards his friends. Hence, loyalty the signified meaning by the symbol of dog in Prisoner of Azkaban.

However, as Arp and Johnson suggested that "a symbol may suggest a cluster of meaning as per the context of the story" (2006: 281), there may be another meaning to the symbol of black dog aside from loyalty. In the quoted passage below, Sirius is depicted to hold grief and sorrow over the death of Harry's parents.

The grief and sorrow he felt over their death are the meaning symbolized by its black fur which is the color often used as a sign of grieving in funeral. Its relation to death also related to the dog's heavy resemblance to the Grim, the harbinger of death in the novel. In this case, the black fur of the dog reflects Sirius' desire for vengeance on whom caused him much sorrow and anguish, his traitorous friend Peter Pettigrew. This desire was so strong that it turned into obsession that enabled him to resist the dementors.

\section{Scabbers the Rat}

The rat Scabbers is a pet belongs to Ron Weasley, Harry's best friend along with Hermione Granger. It is described by a witch working in the Magical Menagerie on Diagon Alley as a common garden rat, but one that "has been through the mill" after she saw its tattered left ear and a front paw that missing a toe (1999: 64-65).

Scabbers' sickly appearance is first noted when Harry encountered Ron and
Hermione in Diagon Alley during the summer holiday.

He pulled his pet rat out of his pocket. "And I want to get him checked over," he added, placing Scabbers on the table in front of them.

"I don't think Egypt agreed with him." Scabbers was looking thinner than usual, and there was a definite droop to his whiskers (1999: 63).

Aside from its bad health condition, Scabbers is also seems to be constantly in fear of something, though often it is because Hermione's cat Crookshanks was after him. However, during Buckbeak's execution, the rat tried to escape frantically from something even when Crookshanks was not around.

"It's Scabbers - he won't - stay put - " Ron was bent over, trying to keep Scabbers in his pocket, but the rat was going berserk; squeaking madly, twisting and flailing, trying to sink his teeth into Ron's hand (1999: 369).

This stress and fear are later revealed by Sirius Black to be because of his escape from Azkaban, and the rat, whom truly is Peter Pettigrew in disguise, knew that Sirius was out for him. The first time his condition is noted to be sick is also recalled by Harry to coincide with the time of Sirius' escape. Accordingly, the position and repeated details of Scabbers' ill condition and fear made it fit to be mention as a symbol.

Scabbers then as a symbol reflects the character of Peter Pettigrew for the rat is his animagus form. Peter is revealed by Sirius to be a spy for Voldemort and a traitor to Harry's parents for selling them out.

Peter as a treacherous man ratted on his friends, James and Lily, giving their location which he supposed to keep secret to Voldemort. Incidentally, his animagus form is also a rat, a small rodent animal. By the double meaning of the word rat, it can be concluded that the rat Scabbers symbolizes betrayal. 
Aside from his treachery, the symbol of rat also reflects two other traits of Peter Pettigrew. First is the cowardice he showed after his deception was revealed. According to Sirius, Peter is "always liked big friends who'd look after him"(1999: 412) and that "his own stinking skin meant more to him than Harry's whole family" (1999: 419). This statement is supported by the fact that Peter tried to beg Sirius and Remus Lupin for mercy.

\section{"Sirius - it's me ... it's Peter ... your friend ... you wouldn't ..." \\ Black kicked out and Pettigrew recoiled. "There's enough filth on my \\ robes without you touching them," said Black. \\ "Remus!" Pettigrew squeaked, turning to Lupin instead, writhing imploringly in front of him. "You don't believe this ... wouldn't Sirius have told you they'd changed the plan?" (1999: 416).}

When the two made clear their intention not to spare him, Peter turned towards Ron and Hermione in desperation, but neither were willing to help him.

Peter even knelt towards Harry, clearly in fear for his life. He tried to convince Harry that his father James, someone he had betrayed, would have understood and show him mercy.

"Harry ... Harry ... you look just like your father ... just like him. ..." ......

"Harry," whispered Pettigrew, shuffling toward him, hands outstretched.

"Harry, James wouldn't have wanted me killed. ... James would have understood, Harry ... he would have shown me mercy. ..."(1999: 417-418).

Conclusively, the symbol of rat in Prisoner of Azkaban signifies several different meanings. It stands for betrayal as Peter Pettigrew sold his best friends whom he had been get along since the school days to Voldemort. The rat is also a symbol for both cowardice and cunning for although Peter is capable of clever trickery, he is a coward who is first and foremost care about his own life and is willing to do anything to save himself.

\section{Dementors of Azkaban}

The dementors are the guardians of Azkaban, a dreadful prison where the Ministry of Magic put the convicted witch and wizard for imprisonment. They are a kind of dark creatures with terrible physical appearance described as follows in Prisoner of Azkaban,

Even more terrible than its appearance is its power to suck happiness and bring despair and hopelessness to its immediate surroundings. As Lupin put it, Dementors are among the foulest creatures that walk this earth. They infest the darkest, filthiest places, they glory in decay and despair, they drain peace, hope, and happiness out of the air around them. Even Muggles feel their presence, though they can't see them. Get too near a dementor and every good feeling, every happy memory will be sucked out of you. If it can, the dementor will feed on you long enough to reduce you to something like itself ... soulless and evil. You'll be left with nothing but the worst experiences of your life (1999: 208-209).

This terrifying power is even more pronounced by its ability called the Dementor's Kiss which enables it to suck the soul of the living. It is, according to Lupin, is "its last and worst weapon, used upon those they wished to destroy utterly" (1999: 274275). To be subjected to the Dementor's Kiss is something Lupin described to be worse than death as he stated that,

You can exist without your soul, you know, as long as your brain and heart are still working. But youll have no sense of self anymore, no memory, no ... anything. There's no chance at all of recovery. You'll just - exist. As an empty shell. And your soul is gone forever ... lost (1999: 275).

As with both the black dog and the rat Scabbers, the dementors of Azkaban is mentioned as a symbol of importance in this study since their recurring appearance 
throughout the story and positioned as an opposition towards Harry, despite being tasked to guard Hogwarts and its students, fits the theory of symbol stated by Arp and Johnson in Perrine's Literature that "the symbol always signals their existence through emphasis, repetition, or position" (2006: 280).

When a dementor first appeared in the story during the ride on Hogwarts Express in an inspection for Sirius Black presence on the train, Harry was immediately subjected to its frightening power.

In his second encounter during the quidditch match however, it is clear that the group of dementors were after Harry specifically.

And then a horribly familiar wave of cold swept over him, inside him, just as he became aware of something moving on the field below. ... Before he'd had time to think, Harry had taken his eyes off the Snitch and looked down. At least a hundred dementors, their hidden faces pointing up at him, were standing beneath him. It was as though freezing water were rising in his chest, cutting at his insides. And then he heard it again. ... Someone was screaming, screaming inside his head ... a woman ... (1999: 198).

Unlike the black dog and the rat which are conventional symbols, the dementor, being a creature invented entirely by J.K. Rowling, is a personal symbol. This is because the meaning it signified as a symbol is defined in accordance to her will as the author as per Abrams theory of symbol (1999: 311). The power of dementors reflected the meaning it signified as a symbol. They drain the positive feeling from their surroundings and leave despair and hopelessness in their wake. A case in point, the reaction of Harry's friends after the encounter with a dementor on the train.

"It was horrible," said Neville, in a higher voice than usual. -Did you feel how cold it got when it came in?"
"I felt weird," said Ron, shifting his shoulders uncomfortably. "Like I'd never be cheerful again. ..."

Ginny, who was huddled in her corner looking nearly as bad as Harry felt, gave a small sob; Hermione went over and put a comforting arm around her (1999: 95).

This feeling of unhappiness along with Harry's own experience of having to relive the memory of his mother's death which left him in misery in his encounters with the dementors on two separate incidents signify that the dementor is a symbol of negativity in form of unhappiness, despair, and misery, as their power instilled such feelings upon their victims, leaving them unable to recall any sort of memory except ones that brings them suffering and hopelessness.

\section{Creature Symbols as Foreshadowing Elements}

In the exposition part of Prisoner of Azkaban, the character Sirius Black, the assumed antagonist of the story, was introduced very early in the third chapter as an escaped convict in the muggle news (1999: 18) before his identity was made clear by the newspaper Stan Shunpike was reading during the Knight Bus ride.

Harry held the paper up to the candlelight and read: BLACK STILL AT LARGE Sirius Black, possibly the most infamous prisoner ever to be held in Azkaban fortress, is still eluding capture, the Ministry of Magic confirmed today.... While Muggles have been told that Black is carrying a gun (a kind of metal wand that Muggles use to kill each other), the magical community lives in fear of a massacre like that of twelve years ago, when Black murdered thirteen people with a single curse (1999: 41).

While Sirius Black is mentioned to be a convicted wizard, it was Stan who revealed that Sirius was a "big supporter of Voldemort" (1999: 42). However, it is to be noted that the revelation of Sirius identity as a supporter of Voldemort was preceded by 
Harry's first encounter with the large black dog suspected to be a Grim (1999: 36-37).

After a brief encounter with the Minister of Magic Cornelius Fudge, Harry then proceeded to spend the rest of summer in Leaky Cauldron while taking occasional trips to Diagon Alley to buy school supplies. When he visited the Flourish and Blotts for new book, he was reminded of coming across the black dog in Magnolia Crescent when he saw the same dog was on the cover of a book about death omens, though later he tried to convince himself that it meant nothing.

Eventually, Harry was reunited with Ron and Hermione again in Diagon Alley. It was in this meeting that Harry first took notice of Scabbers unusual condition, which at the time coincided with the news of Sirius Black escaped from Azkaban (1999: 63) and later, this detail was recalled during the climax of the conflict.

The presumed main conflict of the novel was introduced by the end of summer holiday when Harry accidentally overheard the conversation between Mr. and Mrs. Weasley regarding Sirius Black:

"Molly, how many times do I have to tell you? They didn't report it in the press because Fudge wanted it kept quiet, but Fudge went out to Azkaban the night Black escaped. The guards told Fudge that Black's been talking in his sleep for a while now. Always the same words: 'He's at Hogwarts ... he's at Hogwarts.' Black is deranged, Molly, and he wants Harry dead. If you ask me, he thinks murdering Harry will bring You-Know-Who back to power. Black lost everything the night Harry stopped You-Know-Who, and he's had twelve years alone in Azkaban to brood on that. ..." (1999: 72-73)

In the midst of the ride towards Hogwarts, the train was stopped for an inspection conducted by the dementors of Azkaban in search for Sirius Black. It was during the inspection Harry encountered a dementor for the first time and it forced Harry to relive the moment of his mother's death, albeit the memory was, at the time, limited to the scream of unknown woman.

This encounter is the inciting incident of the plot. It marks the beginning of rising action, the increasing complication of the conflict in the plot, as not only that Harry was in danger from Sirius Black, but the dementors that were stationed around Hogwarts to capture him would not mind preying on him as well. Furthermore, that Harry was forced to relive his mother's death during the encounter foreshadowed that the main conflict would be related to Harry's past. Specifically, the night when his parents were murdered by Voldemort and his subsequent vanquishing the dark lord twelve years ago in Godric's Hollow.

Throughout the rising action part of the plot, the threat of Sirius Black seemed to be looming over Harry. In the first divination lesson where Professor Trelawney predicted his death when she saw that his tea leaves formed the shape of a Grim, a giant, spectral black dog believed by witches and wizards to be an omen of death (1999: 118) and Harry was immediately reminded of the large, doglike silhouette he saw the night at Magnolia Crescent before he boarded the Knight Bus which happened to bear a great resemblance to a Grim. This made him slightly worried, although later McGonagall dismissed her prediction and assured Harry that he would be just fine since none the students whose death were predicted by Trelawney has died yet (1999: 120).

Further into the year, another clue of Sirius' supposed betrayal was given by Malfoy.

"Of course, if it was me," he said quietly, "I'd have done something before now. I wouldn't be staying in school like a good boy, I'd be out there looking for him."

"What are you talking about, Malfoy?" said Ron roughly.

"Don't you know, Potter?" breathed Malfoy, his pale eyes narrowed.

"Know what?" Malfoy let out a low, sneering laugh. 
"Maybe you'd rather not risk your neck," he said.

"Want to leave it to the dementors, do you? But if it was me, I'd want revenge. I'd hunt him down myself" (1999: 140-141).

Malfoy's words, same as Mr. Weasley's, implied that Harry would have wanted revenge on Sirius for a reason unknown to him. At this point however, Harry has yet to know that the reason Sirius was imprisoned years ago was not only for the mass murder he was notorious of, but also for the treason he supposedly had committed by selling his parents to Voldemort twelve years ago.

Despite the looming threat however, the year seemingly progressed smoothly for the students of Hogwarts until Sirius Black managed to sneak into the castle during the student's visiting hour to Hogsmeade and attacked the Fat Lady after he failed in his attempt to enter the Gryffindor common room.

This alerted the whole resident of Hogwarts and instigated the staff to conduct a thorough search around the castle to find Black, albeit to no avail. Since Sirius clearly attempted to enter the Gryffindor common room, this seemed to reinforce the idea that he was after Harry. With the Fat Lady being too frightened to guard the entrance to Gryffindor common room, her portrait was momentarily replaced by Sir Cardogan's while security around the castle was heightened in the light of the incident, especially in the case of Harry who were routinely followed by teachers to ensure his safety.

The quidditch season then began not long after the incident and in $U$ expected turn of event, the Gryffindor were to face Hufflepuff per the request of Slytherin team to switch their match as Malfoy's arm was supposedly not yet healed. It was during the match Harry encountered the Grim for the second time (1999: 197-198), and just as when Harry came across the Grim in the Magnolia Crescent where he almost got crushed by the suddenly appeared Knight Bus, this second encounter was also followed by an incident that nearly killed him. This time by a group of dementors that suddenly appeared on the field. Harry was once again forced to relive the memory of the screaming woman, but this time it was clearer.

Harry realized then that the woman whose scream he had heard was his mother and what the dementors forced him to relive was his memory of Lily begging Voldemort to spare him before the dark lord killed her in the Halloween night twelve years ago. That this memory was shown twice in his two encounters with the dementors signals that the conflict of the novel was not only related to Sirius Black, but also Harry's past regarding the night when his parents were murdered.

The second appearance of the Grim in the quidditch match also worried Harry, especially since near-death accidents seemed to occur every time it showed himself to Harry, making him wonder if the Grim would haunt him to death (1999: 205). The two accidents Harry had experienced seemed to affirm professor Trelawney's prediction regarding Harry's death.

Another thing that made Harry even more nervous was how strongly the dementors affected him. He consulted to Lupin about it and he agreed to teach him a defensive spell against dementors (1999: 210).

In the very last weekend of the first terms, another trip to Hogsmeade was held. Since Harry did not have a signed permission form for the visit, he was not allowed to go, but he was given a way to sneak out from the castle by Fred and George Weasley in form of Marauder's Map.

The map not only showed the people in Hogwarts, but it also showed the secret passages within the castle. This allowed Harry to sneak out into Hogsmeade without anyone's notice. He rendezvoused with Ron and Hermione at the Honeydukes candy shop and spent his time with them. After they finished with their visit to Honeydukes, the three opted for a cup of butterbeer at the 
Three Broomsticks, but unexpectedly, he found out from eavesdropping the minister Cornelius Fudge's conversation with the professors of Hogwarts and the innkeeper Madam Rosmerta that Sirius Black was his parents' best friend, that his parent named him his godfather, and that had supposedly betrayed them to Voldemort.

Another important detail that was revealed in the conversation was the introduction of Peter Pettigrew, the wizard who was allegedly murdered by Sirius Black twelve years ago for confronting the man in the light of his supposed betrayal.

"It was not we who found him. It was little Peter Pettigrew - another of the Potters" friends. Maddened by grief, no doubt, and knowing that Black had been the Potters' Secret-Keeper, he went after Black himself."

"Pettigrew ... that fat little boy who was always tagging around after them at Hogwarts?" said Madam Rosmerta.

"Hero-worshipped Black and Potter," said Professor McGonagall.

"Never quite in their league, talent-wise. I was often rather sharp with him. You can imagine how I - how I regret that now.

..." She sounded as though

she had a sudden head cold.

"There, now, Minerva," said Fudge kindly,

"Pettigrew died a hero's death.

Eyewitnesses - Muggles, of course, we wiped their memories later - told us how Pettigrew cornered Black. They say he was sobbing, Lily and James, Sirius! How could you?' And then he went for his wand. Well, of course, Black was quicker. Blew Pettigrew to smithereens. ..." (1999: 231).

Peter was another friend of James Potter. According to the quoted passage above, he often tagging along with James and Sirius during their Hogwarts days and even heroworshipped them. The passage also mentioned that Pettigrew was the one whom confronted Black for his treason and was murdered for it, according to the muggle witnesses Fudge mentioned.
After the end of Christmas holiday, Harry was getting a lesson from Lupin on an antidementor charm called the Patronus which supposed to act as a shield that chase away the dementors. Lupin used a Boggart, a creature that is able to shapeshift into any person's greatest fear, in place of a real dementor since Harry's Boggart form was one. However, the dementor's effect on Harry was so great that even the Boggart-dementor was able to affect Harry. This time, he also relived the memory of James telling Lily to run when he realized Voldemort was at their doorstep (1999: 267). Nonetheless, Harry managed to produce a decent patronus despite this setback and later, he managed to produce a good one to expel the fake dementors which turned out to be Malfoy and his cronies during the match against Ravenclaw.

Just afterward the Gryffindor's victory party however, another incident occurred. This time, Sirius Black managed to gain entry to the common room and apparently was about to attack Ron.

Sirius escaped before any of the teachers can apprehend him, but this incident vaguely hinted that perhaps Harry was not his target. Harry pondered upon himself on why Black had chosen to escape since he could have easily silenced Ron before he could make a noise and then proceed to attack Harry without anyone's notice instead, though he rationalized that he did so because he would not be able to escape afterwards had he done so (1999: 302).

Just the day before the quidditch final between Gryffindor and Slytherin, Harry saw the Grim once again. Only this time, he saw Hermione's pet cat, Crookshanks, trotting along with it.

And just then, it emerged - a gigantic, shaggy black dog, moving stealthily across the lawn, Crookshanks trotting at its side. Harry stared. What did this mean? If Crookshanks could see the dog as well, how could it be an omen of Harry's death? (1999: 338). 
As is discussed in the first part of the analysis, this was the clue that point towards the possibility that the black dog was not Grim as Harry had first thought since Crookshanks seemed to be able to perceive it normally. That Harry spotted them both later was recalled during the climax of the novel by Harry whom realized that Crookshanks was helping Black all along to get to Peter.

After Gryffindor's triumph in the quidditch final, the second terms was about to end with the exams were underway. At the end of Harry's Divination exam, professor Trelawney unexpectedly prophesied the impending return of Voldemort with the help of a servant whom had been chained for the last twelve years.

Sirius Black seemed to fit the criteria of the servant mentioned in this prophecy. He was thought to be a major supporter of Voldemort, a loyal servant who spied on the Potters by his order, and he had been imprisoned in the dreaded Azkaban for twelve years since his betrayal was revealed to public by Peter Pettigrew. Trelawney predicted that the servant was going to break free before midnight that day and so Harry then immediately set out to find Ron and Hermione to tell them of the prophecy, but before he had the chance to, Ron and Hermione gave him news that Hagrid's hippogriff, Buckbeak, was set to be executed that evening, distracting him from the importance of his own news. This marked the beginning of the climax in the novel where Harry would be confronted by the truth behind his past when Voldemort murdered his parents and was subsequently vanquished, leaving him as the lone survivor of the night.

The three then set out to Hagrid's hut under the cover of Harry's Invisibility Cloak. They accompanied Hagrid before Buckbeak's execution and in the midst of their conversation, Ron's pet rat Scabbers whom had gone missing since the beginning of the second terms, presumably eaten by Crookshanks, suddenly turned up in Hagrid's milk jug (1999: 366-367). The rat looked worse than ever and it behaved frantically as if it was desperate to free himself and escape from something coming after him. When Crookshanks appeared near them when they sneaked out of Hagrid's hut, Scabbers managed to slip away and the cat chased it down until Ron managed to catch it close to the Whomping Willow. But then, the enormous black dog Harry had seen throughout the year suddenly appeared and attacked Ron, dragging him and Scabbers along into the large gap in the Whomping Willow's roots which turned out to be a secret passage.

Ron was on his feet. As the dog sprang back toward them he pushed Harry aside; the dog's jaws fastened instead around Ron's outstretched arm. Harry lunged forward, he seized a handful of the brute's hair, but it was dragging Ron away as easily as though he were a rag doll - ..... And there, at the base of the trunk, was the dog, dragging Ron backward into a large gap in the roots - Ron was fighting furiously, but his head and torso were slipping out of sight - (1999: 372-373).

The quoted passage above showed that the dog was not a Grim all along as it is capable of physically attack Ron while Grim as a spectral being like Hogwarts ghosts was incapable of such feat. This was foreshadowed by the scene when Harry noticed the dog was sneaking around Hogwarts with Crookshanks, which seemed to be able to see it without a problem, as a company. This scene where the Grim that had shadowed Harry all year long suddenly appeared to attack Ron is also a reminiscence to Sirius's attack towards Ron when he was supposed to after Harry instead.

Harry and Hermione then went after the dog into the passage and turned up at the Shrieking Shack where they were confronted by Sirius Black whom turned out to be an animagus who could transform into the black dog that attacked Ron.

This revelation of Sirius Black being an animagus had been foreshadowed early in the novel, specifically during the scene where Harry saw an enormous dog-like silhouette at 
the Magnolia Crescent. This occurred just before Sirius himself was introduced indirectly when Harry saw the newspaper Stan Shunpike was reading in the Knight Bus and thus, vaguely hinted at the possibility above. That the Grim which Black's animagus form resembled was seen as an omen of death also supported this as Black was seen as the greatest threat towards Harry's well-being throughout the year with the minister of magic and the staff of Hogwarts had to ensure his safety personally.

Lupin then entered the scene and both he and Sirius revealed that Ron's pet rat Scabbers was in fact Peter Pettigrew who had been hiding in his animagus form for twelve years. As Lupin explain the background story on how Peter could be disguised as Scabbers when he was supposed to be dead, Sirius never took his eyes off Scabbers, showing obsessive behaviour towards it as if it was a prey. After Pettigrew's cover as Scabbers was blown, Sirius sworn to Harry that he was never a traitor (1999: 415), albeit he felt responsible for James' and Lily's death since he was the one whom arranged the switching of Secret Keeper into Pettigrew (1999: 408), and that the reason he escaped Azkaban was not to going after Harry, but instead he was going after Peter who had betrayed him and his friends to protect Harry from him since he was the only one to know of the truth, thus revealed his true character as a protagonist instead of the assumed antagonist all along.

The revelation that Sirius Black was never a traitor and instead remained a loyal friend of James and Lily all along was vaguely foreshadowed by his animagus form. Though its appearance resembled a Grim heavily, a dog is a common symbol of loyalty which, as it turns out, is an important characteristic of Sirius Black. The black colour of its fur also supported this indirectly as black being the colour that symbolizes sorrow and mourning reflected Sirius' own anguish for the death of his friends since if he was a traitor, he would not have felt such a heavy sorrow for the people he betrayed.

On the other hand, Sirius also showed an obsessive behaviour to capture Pettigrew. He had attacked the portrait of Fat Lady for denying him entry into the common room to capture Peter. He also attacked Ron twice, the first being when he successfully entered the common room by using stolen passwords and the second being when he forcefully dragged Ron who was unknowingly carrying Peter at the time to the Shrieking Shack. Sirius also would have kill Peter had Harry not stopped him by appealing to his friendship with James. These behaviours shows that Sirius has an obsession for vengeance against Peter and this was foreshadowed by the heavy resemblance his animagus form bears to a Grim, a creature believed to be an omen of death. Despite not being a Grim, the black dog's appearance that resembled one do symbolizes Sirius' desire for vengeance and to bring death, only his target was Peter Pettigrew rather than Harry as previously assumed.

The climax in the novel also revealed the truth regarding Peter Pettigrew. He was long thought to die a hero as the conversation between Cornelius Fudge and Hogwarts' staff at the Three Broomsticks revealed, bravely confronted Sirius Black for his betrayal on the Potters and was subsequently killed along with twelve muggles. However, Sirius and Lupin exposed him as an animagus and that he had been under disguise for the last twelve years as a rat.

"I think so," said Lupin, holding Scabbers tightly in one hand and his wand in the other. "On the count of three. One - two - THREE!"

A flash of blue-white light erupted from both wands; for a moment, Scabbers was frozen in mid-air, his small grey form twisting madly - Ron yelled - the rat fell and hit the floor. There was another blinding flash of light and then - It was like watching a speeded-up film of a growing tree. A head was shooting upward from the ground; limbs were sprouting; a moment later, a man was standing where Scabbers had been, cringing and wringing his hands (1999: 409). 
The revelation of Scabbers as Peter was very vaguely hinted as Peter was only mentioned past the inciting incident of the novel which was the train inspection by the dementors at the beginning of the terms. In terms of appearance, both Peter and Scabbers shared a single distinguishing feature: a missing finger. This was what allowed Sirius to see through Peter's trick of faking his death when he saw the Weasleys' photo on the newspaper Fudge had given to him (1999: 405).

Scabbers' sickly appearance and frantic behaviour throughout the year were what truly foreshadowed the revelation. According to Ron, Scabbers had been sick around the time they were on a vacation to Egypt (1999: 63), coinciding with the news of Sirius' escape from Azkaban, and throughout the year, with the threat of Sirius Black was looming over Hogwarts, its condition worsened. It also behaved wildly as if something was after it. Often this was because of Crookshanks that seemed to be obsessed over chasing Scabbers ever since the check-up on the Magical Menagerie, but later it was revealed that Scabbers was trying to catch the rat for Sirius and the reason for the rat's sickly appearance and wild, fearful behaviour was that he knew Sirius would come after him for his betrayal.

Peter's treachery and his clever trick to deceive the magical world of his death were also foreshadowed by his animagus form. The rat in Prisoner of Azkaban as discussed in the previous part of the analysis reflected the aforementioned nature of Peter Pettigrew. Sirius ousted him as the true traitor, revealing that he had been the true Secret Keeper (1999: 415) and the symbol of rat in the novel stands for betrayal. It also stands for cowardice which Peter gave away when begged Sirius and Lupin to spare him the moment his ruse was up and to Ron, Hermione, and Harry when he failed (1999: 417). Lastly, the rat as a symbol of cunning was reflected in Peter's trick of falsifying his death as Scabbers in the second semester of the terms, which in turn foreshadowed the clever ruse he had put up twelve years ago to frame Sirius for his betrayal to the Potters so he could hide away safely.

\section{Conclusion}

As foreshadowing element, the aforementioned symbols were placed throughout the exposition and rising action part of the novel as they cued the readers in for the climax in the conflict of the novel, which was the confrontation of Harry and his past. The symbol of black dog was first appeared at the Magnolia Crescent before the indirect introduction of Sirius Black during Harry's ride on the Knight Bus and then appeared again during Harry's disastrous quidditch match against Hufflepuff. In both cases, the appearance of this black dog was immediately followed by a near-death accident, which led to assumption that the dog was a Grim, an omen of death. However, a vague clue was given that the black dog may not be a Grim when Harry inadvertently noticed that Crookshanks was able to see the dog too, and this was proven when the dog attacked Ron and dragged him to the Shrieking Shack later.

Sirius then was revealed to be an animagus who could transform into the black dog that had been haunting Harry throughout the year and this had been foreshadowed by the first appearance of the black dog at Magnolia Crescent where Harry saw the dog just before the character Sirius Black was indirectly introduced to him as a convicted wizard and a supporter of Voldemort, Harry's nemesis. However, it was revealed in the climax of the novel that Sirius Black was not the traitor to Harry's parents and that he had escaped from Azkaban not to hunt for Harry, but in pursuit of the true traitor, Peter Pettigrew. This was foreshadowed by the black dog's attack on Ron, the owner of Scabbers, theanimagus form of Peter Pettigrew, which was reminiscent to the earlier scene of the novel when Black attacked Ron in the Gryffindor common room. That the black dog shares a resemblance to the Grim that was an omen of death also foreshadowed Sirius' vengeful obsession to catch and kill Pettigrew and his 
blaming himself for the death of his friend as the black colour of its fur symbolizes sorrow and mourning.

The symbol of rat in the novel that was depicted with sickly appearance and wild, fearful behaviour throughout the novel. It was first noted to have a sickly appearance during Harry's summer at Hogsmeade with Ron stating that Scabbers didn't like Egypt, which coincidentally was around the same time the news of Sirius' escape from Azkaban was spread. The rat was depicted to behavewildly and fearful as the year progressed. Often this was because Hermione's pet cat Crookshanks seemed obsessed to catch it and later, it went missing in the beginning of the second semester, presumably eaten by said cat. However, it turned up on Hagrid's hut later and its condition seemed to be worse than ever and even more fearful, frantically tried to escape its owner Ron as if it did not recognize its owner and something was after it. Scabbers then was revealed to be Peter Pettigrew whom was long thought to be dead, but turned out had been hiding all along as the rat, and his former friends, Sirius and Lupin, exposed him as Voldemort's spy and traitor to the Potters. This was foreshadowed by

Scabbers sickly appearance and frantic behaviour throughout the year as the reason for it was, as revealed by Sirius in the climax, that Peter realized the reason Sirius escaped from Azkaban was to hunt him down. Although it was first assumed because of Crookshanks, Harry recalled that Scabbers had been sick before he met Crookshanks in the Magical Menagerie. The black dog's attack on Ron, its owner, which was reminiscent to the scene where Sirius was looming after Ron in his bed, seemingly was about to attack him, also suggested this as well. Furthermore, Peter's treachery to the Potters and his subsequent faking his death and framing Sirius for his action were foreshadowed by the trick Scabbers pulled off to fake its death and framed Crookshanks for it at the start of the terms' second semester.

Lastly, the dementors of Azkaban as the symbol of despair forced Harry to relive the memory of his parents' death thrice. The first was during the train inspection at the start of the terms, the second was during the first quidditch match of the season between Gryffindor and Hufflepuff, and the third was during Harry's anti-dementor lesson with Lupin against a pretending Boggart. These suggested that the conflict would have a relation to the night in Harry's past when his parents were murdered by Voldemort as later revealed when Harry eavesdropped the conversation between the minister and the staff of Hogwarts at Hogsmeade.

To summarize, the dementors as the symbol of fear foreshadowed that the conflict of the novel would be a confrontation between Harry and his past through the act of forcing him to relive the memory of his parents' death thrice, while the symbol of black dog and rat foreshadowed the truth behind said past, that the assumed antagonist of Sirius Black was innocent of the crime he was blamed for and that Peter Pettigrew whom was long thought to die a hero was the one who betrayed the Potters as a servant of Voldemort.

\section{References}

Abrams, M. H. A Glossary of Literary Terms: Seventh Edition. Boston: Thompson Learning, Inc., 1999.

Arp, Thomas R. and Greg Johnson. Perrine's Literature: Structure, Sound, and Sense. Boston: Thompson Wadsworth, 2006.

Barnet, Sylvan, William Burto and William E. Cain. An Introduction to Literature: Fiction, Poetry, and Drama. New York: Pearson Longman, 2008.

"Creature and Color Symbolism in J.K. Rowling's Harry Potter and the Prisoner of Azkaban." Listiyaning Tias. E-Journal. 22 November 2016. 
<https://ejournal.unesa.ac.id/index.php/lite ra-kultura/article/view/3853/6225>.

"Creature". n.d. Oxford Living Dictionaries. 22 November 2016.

$<$ https://en.oxforddictionaries.com/definiti on/creatures.

Cuddon, J.A., A Dictionary of Literary Terms and Literary Theory: Fifth Edition.

Chichester: Wiley-Blackwell, 2013.

"Foreshadowing". n.d. Encyclopaedia Britannica. 22 November 2016.

<https://www.britannica.com/art/foreshad owing $>$.

Guerin, Wilfred L., Earle Labor, Lee Morgan, Jeanne C. Reesman, and John R. Willingham. A Handbook of Critical Approaches to Literature: Sixth Edition. New York: Oxford University Press, 2011.

Haryani, Kristiana Artiningtiyas Budi. "Animal Symbolism to Foreshadow Future Events in George R. R. Martin's A Game of Thrones". Undergraduate Thesis. Yogyakarta: Universitas Sanata Dharma, 2015.

Roberts, Edgar V. and Henry E. Jacobs. Fiction: An Introduction to Reading and Writing. New Jersey: Prentice-Hall, Inc., 1987.

Rowling, J. K. Harry Potter and the Prisoner of Azkaban. London: Bloomsbury, 1999.

Sabarno, Melia H. "The Significance of Hermione Granger to Represent Rowling's School Life in Harry Potter and the Prisoner of Azkaban". Undergraduate Thesis. Yogyakarta: Universitas Sanata Dharma, 2006.

"The Top 100 Bestselling Books of All Time: How Does Fifty Shades of Grey Compare?". n.d. The Guardian. 24 November 2016. <https://www.theguardian.com/news/data blog/2012/aug/09/best-sellingbooks-alltime-fifty-shades-grey-compare>. 